\title{
HORMONE STATUS IN PATIENTS WITH SLIPPED CAPITAL FEMORAL EPIPHYSIS
}

\author{
I. J. BRENKEL, J. J. DIAS, T. G. DAVIES, S. J. IQBAL, P. J. GREGG
}

\author{
From Leicester Royal Infirmary
}

\begin{abstract}
In 15 consecutive patients with slipped capital femoral epiphysis we recorded height, weight and skeletal maturity. Sexual maturity was assessed clinically and biochemically, and Harris's hypothesis that there is an increased ratio of serum growth hormone to oestrogen was tested in comparison with 15 age and sex matched controls.

We found no difference in skeletal or sexual maturity between the groups, or any overt endocrine abnormality in the patients. However almost half the patients with slipped epiphysis were over the 90th weight percentile, suggesting that mechanical factors such as obesity are more important aetiologically than endocrine abnormalities.
\end{abstract}

The fact that slipped capital femoral epiphysis (SCFE) occurs during the rapid growth spurt of puberty and that some of the patients are obese and hypogonadal has led to the suggestion that an endocrine abnormality may play a role in the aetiology of the condition (Waldenström 1940; Harris 1950; Burrows 1957; Sørenson 1968; Ogden and Southwick 1977). Using castrated rats, Harris (1950) demonstrated that growth hormone decreased and oestrogen increased the shear strength of the proximal tibial physeal plate and concluded that an increase in growth hormone relative to oestrogen could predispose to slipping. Although many subsequent case reports support this hypothesis (Table I), many contradict his theory (Table II). Neither Razzano, Nelson and Eversman (1972) nor Gregosiewicz and Pawlik (1980) could establish any abnormality of growth hormone or oestrogen levels in such patients.

Growth hormone brings about the generation of an intermediary hormone known as somatomedin, which in turn acts on the target organ (Macgillvray and Voorhess 1981; Underwood 1985). While the levels of growth hormone fluctuate throughout the day and make accurate assessment difficult (Macgillvray and Voorhess

I. J. Brenkel, BSc, FRCS Ed, Senior Orthopaedic Registrar St. James's Hospital, Beckett Street, Leeds LS9 7TF, England.

J. J. Dias, FRCS, Lecturer in Orthopaedic Surgery

T. G. Davies, MRCP, Biochemist

S. J. Iqbal, MRCP, MRCPath, Consultant in Clinical Chemistry P. J. Gregg, MD, FRCS, Professor of Orthopaedic Surgery

The Departments of Orthopaedic Surgery and Chemical Pathology,

Leicester Royal Infirmary, Leicester LE2 5WW, England.

Correspondence should be sent to Mr I. J. Brenkel.

(C) 1989 British Editorial Society of Bone and Joint Surgery $0301-620 X / 89 / 1002 \$ 2.00$

$J$ Bone Joint Surg [Br] 1989;71-B:33-38
1981), somatomedin shows little or no such fluctuation (Underwood 1985) and can be reliably assessed on a random sample of serum. Both Razzano et al. (1972) and Gregosiewicz and Pawlik (1980) measured the level of ovarian hormones from the excretion of their urinary metabolites. These metabolites are derived from multiple precursors, thereby making any deductions about serum levels inaccurate. The advent of radioimmunoassay has made it possible to measure serum oestrogen, and this method has supplanted the urinary methods (Ross, Van de Wiele and Frantz 1981).

Although it is over 35 years since Harris (1950) proposed his theory and 30 years since somatomedin was discovered (Salmon and Daughaday 1957), there has been no study of serum somatomedin and serum oestrogen in patients with SCFE.

\section{PATIENTS AND METHODS}

Fifteen patients with SCFE and 15 age and sex matched controls were studied. Their age, sex and duration of symptoms were recorded and height and weight percentiles were obtained from standard charts (Tanner and Whitehouse 1972). Their stage of development of secondary sexual characters were assessed using standard illustrations (Forfar and Arniell 1984). Breast development in the girls was graded from 1 to 5 , and genital size in boys from 1 to 5 . The amount of pubertal hair in both groups was also graded from 1 to 5 . Each subject could therefore have a minimum score of 2 and a maximum of 10 . Bone age was assessed from radiographs of the left hand and wrist using the TW2 method of Tanner et al. (1975). The severity of the slip was expressed in degrees using the method of Griffith (1976). 
Before operation and within 24 hours of admission clotted blood samples were taken from each patient. Standard radioimmunoassay techniques were used to determine serum levels of thyroxine $\left(T_{3}\right.$ and $\left.T_{4}\right)$, testosterone and 17-B oestradiol. Thyroid stimulating hormone levels were determined using dissociatedenhanced lanthanide fluoroimmunoassay technique (DELFIA TSH). Serum samples were also stored in aliquots at $-15^{\circ} \mathrm{C}$. The samples were then thawed and somatomedin- $\mathrm{C}$ levels were determined using a radioimmunoassay kit (Immunonuclear Corporation). A 24hour urine sample was obtained for steroid analysis. In particular we were interested in the adrenal androgen excretion in the form of androsterone, aetiocholanolone and dihydroxyepiandrosterone (DHEA).

\section{RESULTS}

There were 9 boys and 6 girls in each group.

Chronological and skeletal age. (Table III). The mean chronological age was similar for the test and control groups in each sex: 14.29 and 14.26 years respectively for the boys and 12.64 and 12.43 years for the girls. The mean delay in skeletal maturation in the test group was mean for the control group was less, at $52.07 \pm 32.98$ (range $<3$ to $>97$ ), the difference was not significant $(p=0.29)$.

Assessed by skeletal age the mean height percentile for the test group $61.80 \pm 31.91$ (range $<3$ to $>97$ ), was not significantly different $(p=0.27)$ from that of the control group, $48.40 \pm 33.41$ (range $<3$ to $>97$ ). Similarly, no significant difference $(p=0.15)$ could be found between the mean weight percentile for the test group at $76.80 \pm 27.53$ (range 10 to $<97$ ) and that for the control group, $52.07 \pm 32.98$ (range $<3$ to $>97$ ).

Duration of symptoms and severity of slip. (Table IV). The mean duration of symptoms was 8.06 months. There was one acute slip with a three-day history and the longest delay was two years. The severity of the slip ranged from 25 to $63^{\circ}$. Ten cases involved the left side, four the right and one was bilateral. There was no correlation between the severity of the slip and delay in making the diagnosis $(p=0.14)$. There was also no correlation between weight and severity $(p=0.35)$.

Sexual maturity. (Tables IV and V). The mean Tanner score was $5.27 \pm 1.75$ (range 2 to 8 ) in the test group. The mean value in the control group was $4.8 \pm 2.4$ (range 2 to $8)$, the difference was not significant $(p=0.55)$. One girl

Table I. Reported cases of slipped capital femoral epiphysis which support Harris's hypothesis (see text)

\begin{tabular}{lll}
\hline Author & Sex & Diagnosis \\
\hline Lofgren 1953 & F & Gigantism \\
Burrows 1957 & F & Gigantism \\
Goldman, Cahill and Thorn 1963 & M & Hypopituitarism with gigantism \\
Sarver et al. 1964 & 2M and IF & Hypopituitarism with gigantism \\
Zimmerman et al. 1967 & 2M & Hypopituitarism with gigantism \\
Primiano and Hughston 1971 & M & Hypogonadism \\
Rennie and Mitchell 1974 & F & $\begin{array}{l}\text { Selective growth hormone deficiency } \\
\text { being treated with growth hormone }\end{array}$ \\
Fidler and Brook 1974 & IM and 1F & Hypopituitarism on treatment \\
Ogden and Southwick 1977 & F & Hypogonadotrophic hypopituitarism \\
Reeves et al. 1978 & F & Gigantism \\
\hline
\end{tabular}

8.86 months \pm 11.87 (range 0 to 31 months). The mean delay in the control group was less: 6.40 months \pm 9.56 (range 0 to 23 months), but the difference was not significant $(p=0.53)$.

Height and weight. (Tables IV and V). Assessed against chronological age the mean height percentile for the test group was $42.46 \pm 27.97$ (range 3 to 80 ). The mean height percentile for the control group was $41.33 \pm 35.32$ (range $<3$ to 95$)$, this difference was not significant $(p=0.92)$. The mean weight percentile for the test group was 65.53 \pm 35.67 (range 5 to $>97$ ). Although the corresponding in the test group was post-menarchal compared to three in the control group. To date three of the test group are post-menarchal compared to four in the control group. Biochemical investigations. (Tables VI and VII). The somatomedin-C levels and 17-B oestradiol levels were similar in the two groups $(p=0.49$ and $p=0.87$ respectively). The serum testosterone and urinary androsterone, aetiocholanolone and DHEA were also similar in both groups $(p=0.49, p=0.17, p=0.37$ and $p=0.40$ respectively). The thyroxine results have been published elsewhere (Brenkel et al. 1988), and showed no signifi- 
Table II. Reported cases of slipped capital femoral epiphysis which contradict Harris's hypothesis (see text)

\begin{tabular}{|c|c|c|}
\hline Author & Sex & Diagnosis \\
\hline Farrow 1953 & $\mathbf{M}$ & Simmond's disease \\
\hline Lofgren 1953 & $\mathbf{M}$ & Craniopharyngioma \\
\hline Tissink 1964 & 4 cases & Hypopituitarism \\
\hline $\begin{array}{l}\text { Semple and Goldschmidt } \\
1969\end{array}$ & $\mathbf{M}$ & Hypopituitary dwarf \\
\hline Moorefield et al. 1976 & $\mathbf{F}$ & Hypopituitarism \\
\hline $\begin{array}{l}\text { Heatley, Greenfield } \\
\text { and Boase } 1976\end{array}$ & $\begin{array}{l}\mathbf{F} \\
\mathbf{F} \\
\mathbf{M} \\
\mathbf{M}\end{array}$ & $\begin{array}{l}\text { Ectopic pinealoma } \\
\text { Optic glioma } \\
\text { Craniopharyngioma } \\
\text { Craniopharyngioma }\end{array}$ \\
\hline Ogden and Southwick 1977 & $\begin{array}{l}\mathbf{M} \\
\mathbf{M}\end{array}$ & $\begin{array}{l}\text { Craniopharyngioma } \\
\text { Craniopharyngioma }\end{array}$ \\
\hline Rappaport and Fife 1985 & 27 cases & $\begin{array}{l}\text { Growth hormone } \\
\text { deficiency }\end{array}$ \\
\hline
\end{tabular}

All patients had hypopituitarism and therefore secondary hypothyroidism

Table III. Chronological and skeletal age for test and control groups

\begin{tabular}{llclll}
\hline & \multicolumn{2}{l}{ Chronological age } & & \multicolumn{2}{l}{ Skeletal age } \\
\cline { 2 - 3 } \cline { 5 - 6 } & SCFE & Controls & & SCFE & Controls \\
\hline Mean & 13.63 & 13.54 & & 12.89 & 13.01 \\
Range & 11.9 to 16.9 & 11.1 to 16.7 & & 11.0 to 15.4 & 11.0 to 15.1 \\
S.d. & 1.47 & 1.44 & & 1.24 & 1.68 \\
P value & & 0.87 & & & 0.83 \\
\hline
\end{tabular}

cant difference in $\mathrm{TSH}, \mathrm{T}_{3}$ and $\mathrm{T}_{4}$ between the two groups.

\section{DISCUSSION}

The aetiology of SCFE is still controversial. Harris (1950) showed than an increase in growth hormone secretion led to an increase in the thickness of the hypertrophied (weakest) layer of the physis. He also suggested that oestrogen, by interfering with growth hormone release from the anterior pituitary, decreased the thickness of the hypertrophied layer. He therefore proposed that an increase in ratio of growth hormone to oestrogen could lead to slipping of the capital femoral epiphysis.

It is now known, however, that growth hormone acts via an intermediary hormone known as somatomedin (Phillips and Vassilopoulou-Sellin 1980; Ross et al. 1981; Underwood 1985). This is an insulin-like peptide which is produced by many tissues, including fibroblasts, and is thought to act locally at the site of origin (Underwood 1985). During puberty the plasma somatomedin- $\mathrm{C}$ concentration increases above adult values and this rise is related to the increasing levels of sex hormone (Rosenfield, Furlanetto and Bock 1983). This is thought to be because oestrogen stimulates, and not (as Harris suggested) inhibits, secretion of growth hormone (Rosenfield et al. 1983). This means that an increased ratio of growth hormone to oestrogen can only be caused iatrogenically or in rare pituitary and gonadal disorders

Table IV. Details of patients with slipped capital femoral epiphysis.

\begin{tabular}{|c|c|c|c|c|c|c|c|c|c|c|c|c|}
\hline \multirow[b]{3}{*}{ Case } & \multirow{3}{*}{$\begin{array}{l}\text { Age } \\
\text { yr }\end{array}$} & \multirow[b]{3}{*}{ mth } & \multirow[b]{3}{*}{ Sex } & \multirow{3}{*}{$\begin{array}{l}\text { Delay } \\
\text { in } \\
\text { diagnosis } \\
\text { (months) }\end{array}$} & \multirow{3}{*}{$\begin{array}{l}\text { Severity } \\
\text { of } \\
\text { slip } \\
\text { (degrees) }\end{array}$} & \multicolumn{2}{|c|}{ Chronological age } & \multicolumn{2}{|c|}{ Skeletal age } & \multirow{3}{*}{$\begin{array}{l}\text { Stage } \\
\text { of } \\
\text { puberty }\end{array}$} & \multirow{2}{*}{\multicolumn{2}{|c|}{ Menarche }} \\
\hline & & & & & & Height & Weight & Height & Woight & & & \\
\hline & & & & & & centile & centile & centile & centile & & yr & mth \\
\hline 1 & 12 & 6 & $\mathbf{M}$ & 1 & 35 & 75 & $>97$ & 75 & $>97$ & 3 & & \\
\hline 2 & 13 & 5 & $\mathbf{M}$ & 12 & 16 & 80 & 50 & $>97$ & 80 & 6 & & \\
\hline 3 & 14 & 6 & $\mathbf{M}$ & 18 & 50 & 25 & 50 & 25 & 50 & 6 & & \\
\hline 4 & 14 & 9 & $\mathbf{M}$ & 12 & 63 & 10 & 90 & 90 & $>97$ & 6 & & \\
\hline 5 & 15 & 1 & $\mathbf{M}$ & 12 & 40 & 20 & 5 & 90 & 60 & 8 & & \\
\hline 6 & 13 & 2 & $\mathbf{M}$ & 1 & 23 & 45 & 10 & 45 & 10 & 4 & & \\
\hline 7 & 13 & 0 & $\mathbf{M}$ & 12 & 50 & 30 & $<97$ & 60 & $>97$ & 3 & & \\
\hline 8 & 16 & 9 & $\mathbf{M}$ & 1 & 60 & $<3$ & 5 & $<3$ & 45 & 4 & & \\
\hline 9 & 15 & 7 & $\mathbf{M}$ & 12 & 30 & 60 & 75 & 70 & 80 & 5 & & \\
\hline 10 & 12 & 0 & $\mathbf{F}$ & 3 days & 35 & 50 & 90 & 50 & 90 & 7 & 12 & 8 \\
\hline 11 & 12 & 5 & $\mathbf{F}$ & 2 & 16 & 20 & 70 & 95 & $>97$ & 5 & - & \\
\hline 12 & 14 & 1 & $\mathbf{F}$ & 24 & 40 & 85 & 45 & 95 & 50 & 7 & 14 & 1 \\
\hline 13 & 12 & 0 & $\mathbf{F}$ & 1 & 30 & 30 & $>97$ & 30 & $<97$ & 6 & - & \\
\hline 14 & 13 & 8 & $\mathbf{F}$ & 12 & * & 75 & 95 & 80 & $<97$ & 7 & - & \\
\hline 15 & 11 & 9 & $\mathbf{F}$ & 1 & 31 & 20 & 95 & 15 & 93 & 2 & 12 & 2 \\
\hline
\end{tabular}

bilateral slip; $\mathrm{L}=15^{\circ} ; \mathrm{R}=35^{\circ}$. 
Table V. Details of 15 control patients

\begin{tabular}{|c|c|c|c|c|c|c|c|c|c|}
\hline \multirow[b]{2}{*}{ Case } & \multirow[b]{2}{*}{$\underset{\mathbf{y r}}{\mathbf{A g e}}$} & \multirow[b]{2}{*}{ mth } & \multirow[b]{2}{*}{ Sex } & \multicolumn{2}{|c|}{$\begin{array}{l}\text { Chronological } \\
\text { age }\end{array}$} & \multicolumn{2}{|c|}{ Skeletal age } & \multirow{2}{*}{$\begin{array}{l}\text { Stage } \\
\text { of } \\
\text { puberty }\end{array}$} & Menarche \\
\hline & & & & $\begin{array}{l}\text { Height } \\
\text { centile }\end{array}$ & $\begin{array}{l}\text { Weight } \\
\text { centile }\end{array}$ & $\begin{array}{l}\text { Height } \\
\text { centile }\end{array}$ & $\begin{array}{l}\text { Weight } \\
\text { centile }\end{array}$ & & yr \\
\hline 1 & 12 & 7 & $\mathbf{M}$ & 95 & 80 & $>97$ & $>97$ & 2 & \\
\hline 2 & 13 & 5 & $\mathbf{M}$ & 10 & 10 & 60 & 60 & 3 & \\
\hline 3 & 13 & 1 & $\mathbf{M}$ & $<3$ & 60 & $<3$ & 60 & 3 & \\
\hline 4 & 14 & 9 & $\mathbf{M}$ & $<3$ & 30 & 25 & 70 & 2 & \\
\hline 5 & 13 & 10 & $\mathbf{M}$ & $<3$ & $<3$ & $<3$ & $<3$ & 3 & \\
\hline 6 & 13 & 5 & $\mathbf{M}$ & 50 & 75 & 50 & 75 & 7 & \\
\hline 7 & 15 & 1 & $\mathbf{M}$ & 70 & 60 & 70 & 60 & 8 & \\
\hline 8 & 15 & 7 & $\mathbf{M}$ & 90 & 75 & 80 & 70 & 6 & \\
\hline 9 & 16 & 7 & $\mathbf{M}$ & 80 & 50 & 85 & 55 & 7 & \\
\hline 10 & 12 & 1 & $\mathbf{F}$ & 10 & 15 & 15 & 30 & 3 & \\
\hline 11 & 11 & 7 & $\mathbf{F}$ & $>97$ & $>97$ & $>97$ & $>97$ & 4 & 12 \\
\hline 12 & 12 & 6 & $\mathbf{F}$ & 40 & 25 & 40 & 20 & 2 & 12 \\
\hline 13 & 13 & 8 & $\mathbf{F}$ & 50 & 85 & 75 & 95 & 6 & 13 \\
\hline 14 & 13 & 0 & $\mathbf{F}$ & 25 & 20 & 25 & 20 & 6 & 12 \\
\hline 15 & 11 & 10 & $\mathbf{F}$ & 15 & 95 & 12 & 92 & 2 & - \\
\hline
\end{tabular}

(Table I). In the majority of cases there does not appear to be an overt endocrine abnormality. Razzano et al. (1972) measured serum growth hormone and urinary oestrogen levels in five patients with SCFE and found no abnormality. Gregosiewicz and Pawlik (1980) found similar results in 27 patients assessed in the same manner. In our study, using more accurate techniques, we were still unable to detect any abnormality of growth hormone or oestrogen secretion.

Thyroxine, however, is more important than either growth hormone or oestrogen in the maturation of the skeletal system (Smeets and Van Buul-Offers 1983). It has been suggested that hypothyroidism may predispose to slipping of the capital femoral epiphysis (Puri et al. 1985). In our earlier study we found no evidence of either sub-clinical or overt hypothyroidism in patients with SCFE (Brenkel et al. 1988).

There is some evidence that adrenal androgens may play a role in the activation of the hypothalamicpituitary-gonadal axis at puberty (Collu and Ducharme 1975). Androgens also increase the strength of the physeal plate (Ogden and Southwick 1977). It is possible therefore that some patients with SCFE may have a low level of androgens which would delay puberty and weaken the physeal plate making it more susceptible to a shearing stress. This would also explain why some patients with SCFE are hypogonadal (Waldenström 1940; Burrows 1957; Sørensen 1968). Our patients with
Table VI. Serum somatomedin-C and 17-B oestradiol levels in patients with slipped capital femoral epiphysis and controls

\begin{tabular}{|c|c|c|c|c|}
\hline & \multicolumn{2}{|c|}{$\begin{array}{l}\text { Somatomedin-C } \\
\text { (nMol//) }\end{array}$} & \multicolumn{2}{|c|}{ 17-B oestradiol (pMol/l) } \\
\hline & SCFE & Controls & SCFE & Controls \\
\hline Mean & 35.8 & 32.1 & 81.7 & 84.5 \\
\hline Range & 15 to 64 & 14 to 80 & $>46$ to 215 & $<46$ to 169 \\
\hline S.d. & 13.0 & 15.9 & 52.23 & 39.40 \\
\hline$P$ value & \multicolumn{2}{|c|}{0.49} & \multicolumn{2}{|c|}{0.87} \\
\hline
\end{tabular}

SCFE had normal pubertal development as compared to the controls, as assessed by pubic hair, breast and genital size. Only one of our cases was post-menarchal at presentation. She was, however, pre-menarchal when her symptoms began two years before presentation. Although our numbers are small, there does not seem to be a delay in menarche in patients with SCFE compared to the controls. These findings are similar to those of Exner (1986) who found no delay in puberty in 27 patients with SCFE and no delay in menarche in seven girls with SCFE. We could detect no abnormality in serum testosterone levels or urinary adrenal androgen excretion in our patients with SCFE.

The diagnosis of SCFE is frequently delayed (Burrows 1957; Brenkel, Prosser and Pearse 1986); the 
Table VII. Adrenal and gonadal hormone levels in patients with slipped capital femoral epiphysis and controls

\begin{tabular}{|c|c|c|c|c|c|c|c|c|c|}
\hline & \multicolumn{4}{|l|}{ Serum levels } & \multicolumn{5}{|c|}{ Urinary levels } \\
\hline & \multicolumn{2}{|l|}{ Testosterone } & \multicolumn{2}{|c|}{ Androsterone } & \multicolumn{2}{|c|}{ Aetiocholanolone } & \multicolumn{3}{|l|}{ DHEA } \\
\hline & SCFE & Controls & SCFE & Controls & SCFE & Controls & SCFE & & Controls \\
\hline Mean & 2.51 & 3.26 & 10.93 & 7.20 & 7.32 & 5.89 & 2.73 & & 1.03 \\
\hline Range & 0.6 to 6.9 & 0.5 to 9.9 & 3.8 to 25.0 & 2.0 to 28.0 & 2.4 to 19.0 & 2.0 to 18.0 & 0.0 to 15.0 & & 0.0 to 7.5 \\
\hline S.d. & 2.11 & 3.52 & 8.10 & 6.54 & 4.37 & 4.18 & 3.84 & & 0.68 \\
\hline$P$ value & \multicolumn{2}{|c|}{0.49} & \multicolumn{2}{|c|}{0.17} & \multicolumn{2}{|c|}{0.37} & \multicolumn{3}{|c|}{0.10} \\
\hline
\end{tabular}

mean delay in our series was 8.6 months. Endocrine status may well have been different at the time the slip occurred, but seven of our patients had had symptoms for less than two months and all of these had normal endocrine function. There was no significant difference in skeletal maturation between our two groups using the TW2 method (Tanner et al. 1975). This is in agreement with Exner (1986) who found no delay in skeletal maturation using a similar method, although both he and Sørenson (1968) found a retarded bone age when using the method of Greulich and Pyle. Seven of our 15 patients with SCFE were over the 90th weight percentile based on chronological age and none were tall and thin. This is similar to other published findings (Burrows 1957; Sørenson 1968; Kelsey, Acheson and Keggi 1972; Exner 1986).

We suggest that the high somatomedin levels that occur during the rapid growth spurt of puberty physiologically weaken the physeal plate by increasing the thickness of the hypertrophied (weakest) layer. For the epiphysis to slip either the duration or degree of vulnerability of the plate must increase or the injuring force must increase. Patients with hypothyroidism (Table II) have delayed fusion of the epiphysis, which prolongs the vulnerable period, while an abnormality of growth or sex hormone (Table I) increases the degree of vulnerability. In most cases of SCFE, however, there is no overt endocrine abnormality. In these patients mechanical factors which increase the stress on the epiphysis, such as obesity, may be the predisposing cause.

No benefits in any form have been received or will be received from a commercial party related directly or indirectly to the subject of this article.

\section{REFERENCES}

Brenkel IJ, Dias JJ, Iqbal SJ, Gregg PJ. Thyroid hormone levels in patients with slipped capital femoral epiphysis. J Ped Orthop 1988:8:22-5.

Brenkel IJ, Prosser AJ, Pearse M. Slipped capital femoral epiphysis: continuing problem of late diagnosis. Br Med J 1986:293:256-7.

Burrows HJ. Slipped upper femoral epiphysis: characteristics of a hundred cases. J Bone Joint Surg [Br] 1957;39-B:641-58.

Collu R, Ducharme JR. Role of adrenal steroids in the regulation of gonadotropin secretion of puberty. J Steroid Biochem $1975: 6: 869-72$.

Exner GU. Growth and pubertal development in slipped capital femoral epiphysis: a longitudinal study. $J$ Pediatr Orthop $1986: 6: 403-9$.

Farrow R. Displacement of the upper femoral epiphysis in a man of twenty-six years suffering from Simmonds disease following a head injury. J Bone Joint Surg [Br] 1953;35-B:432-3.

Fidler MW, Brook CGD. Slipped upper femoral epiphysis following treatment with human growth hormone. J Bone Joint Surg [Am] 1974;56-A:1719-22.

Forfar JO, Ameil GC. Textbook of paediatrics. Vol. 1. 3rd ed. Edinburgh, etc: Churchill Livingstone, 1984.

Goldman JK, Cahill CG, Thom GW. Gigantism and hypopituitarism. Am Med $J$ 1963;34:407-16
Gregosiewicz A, Pawlik B. Rezerwa czynnościowa przysadki w zakresie wydzielania hormonu wzrostu i wydalanie 17-ketosterydow u pacjentów z mlodzieńczym zluszezeniem glowy kości udowcj. Chiradow Narz Ruchu Ortop Pol 1980;45(4):347-52. (Eng.Abstr.)

Griffith MJ. Slipping of the capital femoral epiphysis. Ann R Coll Surg Engl 1976;58:34-42.

Harris WR. The endocrine basis for slipping of the upper femoral epiphysis: an experimental study. J Bone Joint Surg [Br] 1950:32-B:5-11.

Heatley FW, Greenwood RH, Boase DL. Slipping of the upper femoral epiphyses in patients with intracranial tumours causing hypopituitarism and chiasmal compression. J Bone Joint Surg [Br] 1976:58-B:169-75.

Kelsey JL, Acheson RM, Keggi JK. The body build of patients with slipped capital femoral epiphysis. $A m$ J Dis Child 1972:124:276-81.

Lofgren L. Slipping of the upper femoral epiphysis, signs of endocrine disturbance, size of sella turcica, and two illustrative cases of simultaneous slipping of the upper femoral epiphysis and tumour of the hypophysis. Acta Chir Scand 1953;106:153-65.

Macgillvray MH, Voorhess ML. Disorders of growth and development. In: Felig P, Baxter JD, Broadus AE, Frohman LA, eds. Endocrinology and metabolism. New York, etc: McGraw-Hill Book Co, $1981: 1307$ 
Moorefield GW Jr, Urbaniak JR, Ogden WS, Frank JL. Acquired hypothyroidism and slipped capital femoral epiphysis: a report of three cases. J Bone Joint Surg [Am] 1976;58-A:705-8.

Ogden JA, Southwick WO. Endocrine disfunction and slipped capital femoral epiphysis. Yale J Biol Med 1977;50:1-16.

Phillips LS, Vassilopouloui-Sellin R. Somatomedins. (First of two parts). N Engl J Med 1980;302:371-80.

Primiano GA, Hughston JC. Slipped capital femoral epiphysis in a true hypogonadal male (Klinefelter's mosaic $X Y / X X Y)$ : a case report. $J$ Bone Joint Surg [Am] 1971;53-A :597-601.

Puri R, Smith CS, Malhotra D, et al. Slipped upper femoral epiphysis and primary juvenile hypothyroidism. J Bone Joint Surg [Br] 1985;67-B:14-20.

Rappaport EB, Fife D. Slipped capital femoral epiphysis in growth hormone-deficient patients. Am J Dis Child 1985;139: 396-9.

Razzano CD, Nelson C, Eversman J. Growth hormone levels in slipped capital femoral epiphysis. $J$ Bone Joint Surg [Am] 1972;54-A :1224-6.

Reeves GD, Gibbs M, Paulshock BZ, Rosenblum H. Gigantism with slipped capital femoral epiphysis. Am J Dis Child 1978:132:529-30.

Rennie W, Mitchell N. Slipped femoral capital epiphysis occurring during growth hormone therapy: report of a case. J Bone Joint Surg [Br] 1974:56-B:703-5.

Rosenfield RI, Furlanetto R, Bock D. Relationship of somatomedin-C concentration to pubertal changes. J Pediatr 1983;103: 723-8.

Ross GT, Van de Wiele RL, Frantz AG. The ovaries and the breasts. In: Williams RH, ed. Textbook of endocrinology. 6th ed. Philadelphia, etc: WB Saunders Co, 1981:363.
Salmon WD Jr, Daughaday WH. A hormonally controlled serum factor which stimulates sulfate incorporation by cartilage in vitro. $J$ Lab Clin Med 1957;49:825-36.

Sarver ME, Sabeh G, Fetterman GH, et al. Fractional hypopituitarism with gigantism and normal sella turcica. $N$ Engl $J \mathrm{Med}$ $1964 ; 271: 1286-9$

Semple JC. Goldschmidt RG. Epiphyseal maturation and slipping of the femoral epiphysis in a hypopituitary dwarf. Orthopaedics $1969 ; 2: 31-42$.

Smeets T, Van Buul-Ofiers S. The influence of growth hormone, somatomedins, prolactin and thyroxine on the morphology of the proximal tibial epiphysis and growth plate of Snell dwarf mice. Growth 1983;47:160-73

Sorenson KH. Slipped upper femoral epiphysis: clinical study on aetiology. Acta Orthop Scand 1968;39:499-517.

Tanner JM, Whitehouse RH. Growth and development chart. Ware: Castlemead Publications, 1972.

Tanner JM, Whitehouse RH, Marshall WA, Healy MJR, Goldstein H. Assessment of skeletal maturity and prediction of adult height (TW2 method). London: Academic Press, 1975.

Tissink J. Proceedings of the Netherlands Orthopaedic Society. $J$ Bone Joint Surg [Br] 1964;46-B:573.

Waldenström H. Slipping of upper femoral epiphysis. Surg Gynecol Obstet 1940;71:198-210.

Underwood LE. Somatomedin-C in clinical diagnosis. ICPR $1985 ;$ Sept/Oct :13-7.

Zimmerman TS, White MG, Daughaday WH, et al. Hypopituitarism with normal or increased height: report of two cases with measurement of plasma growth hormone levels. Am J Med 1967;42:146-50. 